Bartın Üniversitesi

Eğitim Fakültesi Dergisi

Cilt 6, Sayı 1, s. 139-158, Subat 2017

BARTIN - TÜRKIYE

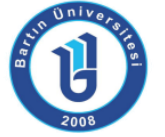

ISSN: 1308-7177
Bartin University

Journal of Faculty of Education

Volume 6, Issue 1, p. 139-158, February 2017

BARTIN - TURKEY

\title{
Resim Anasanat Atölye Dersi Öğrencilerinin Resimde Mekân Konusuna İlişkin Görüşlerinin Değerlendirilmesi
}

Aylin BEYOĞLU, Arş. Gör. Dr., Trakya Üniversitesi Eğitim Fakültesi, aylinbeyoglu@trakya.edu.tr

Melek AKYÜREK, Yrd. Doç. Dr., Abant İzzet Baysal Üniversitesi Güzel Sanatlar Fakültesi, melekabut@hotmail.com

Öz: Araştırmanın temel amacı; Üniversitelerin Eğitim Fakülteleri Güzel Sanatlar Eğitimi Bölümü Resim-İş Eğitimi Anabilim Dalı Resim Anasanat Atölye öğrencilerinin resimde mekân konusunda genel bilgileri, görüşleri hakkında bilgi edinmek ve görüşlerini değerlendirmektir. Araştırmanın çalışma grubu, 2016-2017 Eğitim-Öğretim yılında, Edirne ilinde bulunan Trakya Üniversitesi Eğitim Fakültesi Güzel Sanatlar Eğitimi Bölümü Resim-İş Eğitimi Anabilim Dalı Resim Anasanat Atölye öğrencileri ve Bolu ilinde bulunan Abant İzzet Baysal Üniversitesi Eğitim Fakültesi Güzel Sanatlar Eğitimi Bölümü Resim-Iş Eğitimi Anabilim Dalı Resim Anasanat Atölye öğrencileri olmak üzere toplam 101 öğrenciden oluşmuştur. Araştırma ilişkisel tarama modeli ile oluşturulmuş, resimde mekân konusu ile sınırlandırılmıştır. Araştırmada resimde mekân ile ilgili hazırlanan "Resimde Mekân Ölçeği" ve "Kişisel Bilgi Formu" kullanılmıştır. Araştırmanın sonucunda, öğrencilerin resimde mekân kavramı ile ilgili görüşleri incelenerek, "Kişisel Bilgi Formu"ndaki faktörler "Resimde Mekân Ölçeği"ndeki sorularla karşılaştırılarak değerlendirilmiştir. Araştırmanın, Güzel Sanatlar Eğitimi Bölümü Resim-İş Eğitimi Anabilim Dalı’nda yetiştirilen öğrencilerin niteliklerinin geliştirilmesinde katkı sağlayacağı düşünülmektedir.

Anahtar Kelimeler: boşluk, eğitim, mekân, sanat, sanatçı, resim

\section{Evaluation of the Opinions of Painting Art Major Workshop Class Students on the Subject of Locale in Painting}

Abstract: The fundamental purpose of this study is to gain information on and evaluate the opinions of the students in Education Faculties, Fine Arts Education Departments, Painting-Handcraft Department, Painting Major Workshop Students in Universities on the subject of location in painting. The study group comprises a total of 101 students from Education Faculty, Fine Arts Education Department, Painting-Handcraft Department, Painting Major Workshop Students of Trakya University in Edirne Province and Education Faculty, Fine Arts Education Department, Painting-Handcraft Department, Painting Major Workshop Students of Abant İzzet Baysal University in Bolu Province. The study has been conducted using the relational screening model and has been limited to the subject of location in painting. The "Location in Painting Scale" and "Personal Information Form", prepared for the subject of location in painting, have been used in the study. In this study, In this study, the opinions of students on the subject of location in painting have been examined and the factors in personal information form have been evaluated in comparison with the questions in the "Location in painting scale". It is believed that the study will contribute to the development of students' qualifications in Fine Arts Education Department Painting-Handcraft Major.

Key Words: space, evaluate, locale, art, artist, painting 


\section{GíRiş}

Güzel sanatlar eğitimi, sanatın yaşamdaki yerini, anlamını ve önemini kavratacak biçimde düzenlenmiş belli programlar aracılığı ile çeşitli dallarında beceri kazandırarak yaratıcı güçlerini ortaya çıkarabilecek uygulama çalışmaları ve sanatsal yaratma olgusunu tanıtmaya yönelik bir eğitim sürecidir (San, 1987). Güzel sanatlar eğitimi, eğitim biliminin bir dalı olarak sanatın, estetiğin, sanat tarihinin eğitim ve öğretimiyle ilgili bir alandır. Bireyin sanatsal ve estetik gelişimi, sanatta öğrenme ve yaratıcılık eğitimi güzel sanatlar eğitimi ve öğretiminin konuları içinde yer almaktadır. Güzel sanatlar eğitimi; resim, heykel, seramik, grafik tasarımı, tekstil tasarımı, özgünbaskı, endüstriyel tasarım, fotoğraf gibi oldukça geniş bir alanı kapsamaktadır. Bu dalların tümüyle ilintili olarak okul öncesinden yükseköğretime kadar her aşamadaki sanat eğitimi ve öğretimiyle ilgili kurumsal ve uygulamalı çalışmalar "görsel sanatlar eğitimi" ya da daha genel bir ifade ile "sanat eğitimi" olarak tanımlanmaktadır (Kırışoğlu, 2005, 2-3). Sanat eğitimi; gençlere estetik yargı yapabilme konusunda yardımı amaçlarken, yeni biçimleri hissedip, eğlenmeyi ve heyecanlarını doğru biçimlerde yönlendirmeyi öğretmektedir (Hausman, 1985). Bu eğitim sürecinde sanat eğitiminin yöntemi ile ilgili sorunlara felsefe, psikoloji, sosyoloji ve antropoloji gibi bilim dallarıyla ilişki kurarak üst düzeyde çözümler aranmakta, bulunan çözümleri uygulamaya sunmaktadır. Kuramı oluştururken bu dalların bilimsel araştırmalarından, araştırma yöntem ve tekniklerinden yararlanmaktadır (Kırışoğlu, 2005, 3).

Eğitim Fakülteleri, Güzel Sanatlar Eğitimi Bölümlerinde yer alan Resim-iş Öğretmenliği Anabilim Dallarının amacı; Milli Eğitim Bakanlığı bünyesindeki olan ve olmayan kurumlarda ilk ve ortaöğretim kurumlarına, alanında nitelikli resim-iş öğretmeni ya da sanat eğitimcisi yetiştirmektir. Eğitimcinin öğrencilere neyi, niçin ve nasıl öğreteceğini bilmesi ve bu eğitimin sonunda alacağı dönütleri daha önceden programlayıp belirleyebilecek seviyeye ulaşmış olması gerekmektedir. Bu doğrultuda bu dallarda verilen derslerin içerikleri ve verilen bilgilerin ne kadar sağlam bir temel oluşturduğu önem taşımaktadır.

T.C. Yüksek Öğretim Kurulu Başkanlığı (1998) Eğitim Fakülteleri Öğretmen Yetiştirme Programları Resim Öğretmenliği Lisans Programı Resim Öğretmenliği Lisans Programı Ders Tanımları içerisinde yer alan Anasanat Atölye Resim dersi içeriğini şu şekilde belirtmiştir: Resim Anasanat Atölye I dersi III. yarıyıldan itibaren başlamaktadır. Ancak sadece Resim dersi olarak değil, Grafik Tasarımı, Heykel, Tekstil Tasarımı, Seramik, Geleneksel Türk Sanatları, Özgünbaskı, Endüstriyel Tasarım, Fotoğraf gibi diğer anasanat dalları da yer almaktadır. Öğrenci bu derslerden birini seçme hakkına sahiptir. Adları yazılı dokuz adet Anasanat Atölye dersleri Resim-Iş Eğitimi Bölümlerinin öğretim elemanı ve fiziki ortamı ile kapasiteleri dikkate alınarak seçmeli ders olarak düzenlenmektedir. Anasanat Atölye dersleri altı yarıyıl süresince verilmektedir. Eleman ve atölye olanakları sınırlı bölümler bu dersleri mevcut durumlarına göre düzenlemektedir. Ancak geleceğe dönük olarak Anasanat Atölye derslerinin çeşitlendirilmesine, eleman, atölye sayısı ve olanaklarının artırılmasına önem verilmesi beklenmektedir (Yüksek Öğretim Kurulu Başkanlığı, 1998, 85). Bu derslerin içerikleri ve uygulanış biçimleri şu şekilde verilmektedir:

"Resim I-II-III-IV-V-VI: Temel resim kuram ve kavramları, bir resmi dönem, teknik ve içerik bakımından analiz edebilecek görsel ve kültürel bilgi ve beceriler, resmin özgün bir ifade aracı olarak algılanması, farklı teknik ve malzemeleri deneyip, sanat eserleriyle örnekleyerek kendi eğilimlerine uygun görsel bir dil oluşturma yeterliliğini geliştirici çalışmalar." (Resim-iş̧ Öğretmenliği Lisans Programı, 2016).

Trakya Üniversitesi, Eğitim Fakültesi, Güzel Sanatlar Eğitimi Bölümü Resim-i̇ş Eğitimi Anabilim Dalında altı yarıyıl süresince Resim Anasanat Atölye dersi verilmektedir. Fakat III. 
yarıyıldan itibaren 2.sınıfta Anasanat Atölye I-II, 3. sınıfta Anasanat Atölye III-IV ve 4. sınıfta Anasanat Atölye V-VI olmak üzere öğrencilerin Anasanat Atölye derslerinde sadece Resim Anasanat Atölye dersi bulunmaktadır. Öğrencilerin bu ders için seçim hakkı bulunmamaktadır. I. öğretim için kontenjan 30 öğrenci olarak belirlenmiştir. Öğrenciler söz konusu olan derslerde $A$ ve $B$ grubu olmak üzere yaklaşık 15 kişi olarak ikiye ayrılmaktadır.

Abant İzzet Baysal Üniversitesi, Eğitim Fakültesi, Güzel Sanatlar Eğitimi Bölümü Resimİ̧ Eğitimi Anabilim Dalında altı yarıyıl süresince Resim Anasanat Atölye dersi verilmektedir. 2.sınıfta III.-IV. yarıyılda Anasanat Atölye I-II dersi Resim ve Grafik olmak üzere, 3. sınıfta III-IV. yarıyılda Anasanat Atölye III-IV dersi Resim ve Grafik olmak üzere iki anasanat dalına, 4. sınıfta ise V.-VI. yarıyılda Anasanat Atölye V-VI dersi Resim, Fotoğraf ve Grafik olmak üzere üç anasanat dalına ayrımaktadır. I. Öğretim için kontenjan 40 öğrenci olarak belirlenmiştir (AKST Bilgi Kataloğu, 2016a). Abant İzzet Baysal Üniversitesi, Eğitim Fakültesi, Güzel Sanatlar Eğitimi Bölümü Resim-Iş Eğitimi Anabilim Dalında Resim Anasanat Atölye dersinin öğretim üyeleri dersin amaçlarını şu şekilde belirtmiştir:

"Görsel sanat eleman ve ilkelerini kullanarak kompozisyon tasarlamak, Görsel sanatların temel kavramlarını açıklamak, Görsel sanatlarda kullanılacak araç, gereç ve materyalleri kullanarak, sanat elemanları ile ilkelerini birbirleri ile ilişkilendirmek, Görsel sanat örnekleri ile öncü sanatçıların eserlerini tartışmak, Görsel sanatlar uygulamalarını etkileyen üslup ve kuramları analiz etmek, Görsel sanatlar uygulamalarında kullanılan yöntem ve teknikleri çalışmalarına aktarabilme, Görsel sanatlar eğitimine yönelik kaynakları değerlenmektir. Dersin içeriği ise; Görsel sanat eleman ve ilkelerini kullanarak kompozisyon tasarlama becerisi kazandırma, görsel sanatlarının araç, gereç ve materyalleri kullanarak formbiçim oluşturma becerisi kazandırma olarak belirlenmiştir." (AKST Bilgi Kataloğu, 2016b).

Bu amaçlar göz önünde bulundurularak Resim-iş Öğretmenliği Anabilim Dalı Anasanat Atölye Resim Dersi kapsamında resimde mekân ders içeriğinde yer alması gereken konulardan biri olduğu düşünülmektedir. Güzel Sanatlar Eğitimi Bölümlerinde çalışmakta olan öğretim elemanları, mekân kavramının bu ders içerisindeki önemini vurgulamaktadır. Anasanat Atölye Resim Dersi kapsamında mekânın temel öğeleri ve mekânı etkileyen faktörlerin işlevlerine bağlı olarak resimlerinde mekânı düzenleme biçimlerinde öğrencilerin üzerinde etkili olduğunu belirtmektedirler. Bu doğrultuda araştırmada, Güzel Sanatlar Eğitimi Bölümü Resim-iş Eğitimi Anabilim Dalı Anasanat Atölye Resim Dersi kapsamında öğrenciler resimde mekân konusu hakkında genel bilgilere sahip midir? Resimde mekân konusu hakkında ne gibi sorunlarla karşı karşıya kalıyorlar? Resimlerinde mekânı nasıl oluşturuyorlar? Mekân konusunda Anasanat Atölye derslerinde verilen bilgiyi yeterli görüyorlar mı? Resimlerinde mekâna ne kadar önem veriyorlar? gibi araştırmanın problem durumunu oluşturan sorulara cinsiyet, sınıf, üniversite, mezun olduğu lise, yetenek sınavını kazanmadan önce resim kursu alıp almadığı, resim kursu aldıysa kaç yıl aldığı, ders dışında resim yapıp yapmadığı, yapıyorsa haftada kaç saat yaptığı gibi faktörlerin etkisinin olup olmadığına cevap aranmış ve değerlendirme bu faktörlere göre yapılmıştır.

\subsection{Resimde Mekân Kavramı}

Mekânı genel anlamda "insanın, insan ilişkilerinin ve bu ilişkilerin gerektirdiği donatıların içinde yer aldığı, sınırladığı kapsadığı örgütlenmenin yapı ve karakterine göre belirlenen bir boşundur." olarak tanımlayabiliriz (Gür, 1996, 32). Bunun yanı sıra mekân, insanın içinde bulunduğu mimarinin dördüncü boyutu olarak da tanımlanabilir. Böylelikle mekân; en, boy ve yüksekliğin ötesinde, bireyin devingenliğinden kaynaklanan, dördüncü boyutu kazanmaktadır. Mekân boyutunun kişinin devingenliği ile yaşamın içerisine kattığı 
zengin kullanım özgürlüğünden ötürü mimarinin birinci elemanı olma özelliğini oluşturup "birinci boyut" tan bahsedebilmeyi olanaklı kılmaktadır (Sözen ve Tanyeli, 1992, 36).

Mekân kavramı ve mekânın resim sanatındaki temsilleri, tarih boyunca birçok değişime uğramış ve plastik sanatların vazgeçilemez bir konusu olmuştur. Mekân kavramının içerisinde yer alan temel öğelerin ve mekânı etkileyen temel faktörlerin uğradığı değişimler, mekânın başlı başına tanımlanması, kavranması ve anlamlandırılması gereken plastik bir sorun olarak karşımıza çıkmaktadır. Sabit bir gelişim çizgisinden bahsedemeyeceğimiz mekânın ne olduğuna dair birkaç binyıldır farklı tanımlar yapılmıştır. Beyhan (2007)'de yaptığı araştırmasında konu ile ilgili problemi şu şekilde belirtmiştir:

"Mekân resim sanatının temsil öğelerinden biri ve sanat tarihi sınıflandırması açısından ayırt edici göstergelerden olduğuna dair şüphe yoktur. Ancak resimde mekânın ne olduğuna dair genel anlamda geçerli bir tanım vermek çokta kolay değildir... Sorun resim içinde mekâna ait olan ve olmayanı ayırt etmedeki güçlükle başlar. Çünkü bu, öncelikle bilim ve felsefede birkaç binyıldır tartışılan bir probleme götürür bizi, o da mekânın ne olduğudur."(s.1).

Plastik sanatlarda plastik bir dil ve temsil yoluyla daha geniş kapsamlı ele alınarak sorgulanan mekân kavramını tanımlayacak olursak: resimde mekân, biçimlerin dışında, nesnelerin ya da figürlerin etrafındaki ve aralarındaki boşluktur. Bu boşluk, kesilip çıkarılan figürün ardında kalan amorf alandır. Diğer bir anlayışla tanımlarsak: biçimlerin birbirlerine olan konumları ve hacimlerinde bulunarak onları var eden, yerçekimine ve pozisyonlarına göre onları ayakta tutan, her yerde olan ama görülmeyen, yalnızca plastik bir dil ve temsil yoluyla ifade edilebilendir (Ülker, 2014, 1). Mekâna plastik bir dille boşluğun karşılığı olarak yorumlama olarak bakarsak Karasu (2006)'da yaptığı araştırmasında mekân konusunu şu şekilde ifade etmiştir:

"Mekân boşluğun karşılığı olarak düşünüldüğünde, boşluğu görünür kılan şey, onun nesnelerle doldurulmuş halidir. Bu anlamda mekân, sınırları nesnelerin birbirleriyle olan konumları ölçüsünde belirlenmiş bir alandır. Mekânın algılanışı da bu yolla gerçekleşir. Nesnelerin birbirlerine göre konumları, ilişkileri tarif edilirken aslında mekân tarif edilmiş olur. Mekân ancak bu yolla tarif edilebilir. Mutlak boşluğu görünür kılan nesnelerdir, boşluk nesneler yoluyla tarif edilmiş olur. Sanatçının yaptığı şeyde boşluğu düzenlemektir bir anlamda." (s. 33).

Diğer bir açıdan bakılacak olursa bir sanat eserinde mekân, bir boşluk olmayıp; büyük ölçüde bir varlık olarak görülebilir. Bir sanat eseri; çizgileri, şekilleri, renkleri ve dokularıyla, anlam vermek üzere etkileşim içinde olan dinamik bir görsel öğedir. Bir resmin yüzeyi; köşeleri ve resim düzleminin iki boyutuyla birlikte tanımlanabilir. Ancak bu sınırlı alanda bile sonsuz sayıda mekânsal özelliği bir arada barındırabilir (Öztuna, 2007, 144). Uysal (2009)'da yaptığı araştırmasında mekân kurgusu ile ilgili düşüncelerini şu şekilde belirtmiştir: "Mekân kurgusu, dış dünyanın gerçekleri, nesneleri tarafından sınırları çizilen bir hacmi tanımlamaktan çok, algıya dayalı tinsel bir olabilirlikler alanı olarak kabul edilmelidir. İçinde eylemin olduğu, kendini sonsuz boşluktan ayıran, insanlık tarihi birikimine dayanan algılar bütünüdür." (s. 4).

Resimde kullanılan mekân; plastik bir dil ve temsil yoluyla mekânın içerisinde yer alan temel öğelerin ve mekânı etkileyen temel faktörlerin, boşluğun öznel bir yorumuyla, insan vücuduyla olan ilişkisiyle, düşlerin yansıtılmasıyla, doğanın görüntüsünün kullanımıyla ya da soyut bir kurgulama ile betimlenerek bir araya gelmesiyle oluşabilir. Bu oluşumda temel öğelerin ve faktörlerin yanı sıra; figür-mekân ve nesne-mekân ilişkisi, biçimlerin birbirini eritmesi, kapaması veya gizlemesi, fırça vuruşlarının birbirini örtmesi, renklerin birbirini eritmesi, kapaması veya gizlemesi, biçimlerin tekrarları, şeffaf yüzeyler, resimsel kompozisyon ve kompozisyondaki motifler ve motifler arasında boşluklar da büyük rol oynamaktadır. 
Mekânı zaman ve uzam kavramlarından bağımsız düşünemeyiz. Karasu (2006)'da konuyu şu şekilde yorumlamıştır:

"Varoluşunu uzam ve zaman boyutu içerisinde algılayan insan, çevresindeki nesneleri de uzamda ve zamanda görür. Her varlık, her nesne uzamda ve zamandadır. Sanat yapıtı da belli bir uzam ve zamanla kuşatılmışlığın yanı sıra, öznelliği ile uzamsallığa ve zamansallığa sahiptir. Bulunduğu yer-nesnel dünyadaki yeri- ve zaman boyutundan başka, kendisini oluşturan bir uzamsallığı ve zamansallığı vardır. Sanat yapıtı bir anlamda uzam ve zamanın düzenlenmesidir. Sanatçı hangi disiplin içinde üretirse üretsin, hangi elemanları kullanırsa kullansın öncelikle uzam ve zamanı kullanır. Yapmış olduğu şey ilk olarak uzam ve zamanda anlam bulacaktır." (s. 33).

\section{YÖNTEM}

Bu bölümde yöntem ele alınmıştır. Araştırmanın modeli, evren ve çalışma grubu, araştırmada kullanılan veri toplama araçları, verilerin toplanması, verilerin çözümlenmesine yer verilmiştir.

\subsection{Araştırmanın Modeli}

Araştırmanın yöntemi ilişkisel tarama modelidir. İki ya da daha çok değişken arasında birlikte değişim varlığını belirlemeyi amaçlayan tarama yaklaşımına ilişkisel tarama yaklaşımı denir. Korelasyon ve karşılaştırma bu gruba girmektedir (Karasar,1984, 83). Bu araştırmada her iki üniversitenin Eğitim Fakülteleri Güzel Sanatlar Eğitimi Bölümü Resim-iş̧ Eğitimi Anabilim Dalı Resim Anasanat Atölye derslerinde yer alan resmin temel elemanlarından biri olan resimde mekân konusu hakkında öğrencilerin görüşleri karşılaştırılmıştır.

\subsection{Evren ve Çalışma Grubu}

Araştırmanın çalışma grubu, 2016-2017 Eğitim-Öğretim yılında, Edirne ilinde bulunan, Trakya Üniversitesi Eğitim Fakültesi Güzel Sanatlar Eğitimi Bölümü Resim-I̧̧ Eğitimi Anabilim Dalı Resim Anasanat Atölye öğrencileri ve Abant İzzet Baysal Üniversitesi Ĕgitim Fakültesi Güzel Sanatlar Eğitimi Bölümü Resim-Iş Eğitimi Anabilim Dalı Resim Anasanat Atölye öğrencileri olmak üzere her iki üniversiteden toplam 101 öğrenci araştırmaya dâhil edilmiştir. Araştırmaya dâhil edilen öğrencilerin demografik özellikleri ile ilgili genel tanımlayıcı bilgileri şu şekildedir:

Trakya Üniversitesi çalışma grubu öğrencilerinin 53'ü $(\% 82,8)$ kız, 11' i $(\% 17,2)$ erkek; Abant İzzet Baysal Üniversitesi çalışma grubu öğrencilerinin ise 27'si $(\% 73,0) \mathrm{kız}, 10$ 'u $(\% 27,0)$ erkektir. Trakya Üniversitesi çalışma grubu öğrencilerinin 4'ü $(\% 6,3) 19$ ve daha küçük, 37'si $(\% 57,8)$ 20-21 yaş aralığında, 19'u (\%29,7) 22-24 yaş aralığında, 4'ü $(\% 6,3) 25$ ve üstü; Abant İzzet Baysal Üniversitesi çalışma grubu öğrencilerinin ise 9'u $(\% 24,3) 19$ ve daha küçük, 20'si $(\% 54,1) 20-21$ yaş aralığında, 5’i $(\% 13,5) 22-24$ yaş aralığında, 3’ü $(\% 8,1) 25$ ve üstüdür. Trakya Üniversitesi çalışma grubu öğrencilerinin 22'si (\%34,4) 2. sınıf, 20'si (\%31,3) 3. sınıf, 22'si $(\% 34,4)$ 4. sınıf; Abant İzzet Baysal Üniversitesi çalışma grubu öğrencilerinin ise 12'si $(\% 32,4) 2$. sınıf, 12'si $(\% 32,4)$ 3. sınıf, 13'ü $(\% 35,1)$ 4. sınıftır. Trakya Üniversitesi çalışma grubu öğrencilerinin 21'i $(\% 32,8)$ Güzel Sanatlar Lisesi mezunu, 43'ü $(\% 67,2)$ diğer liselerden mezun; Abant İzzet Baysal Üniversitesi çalışma grubu öğrencilerinin ise $19^{\prime} u(\% 51,4)$ Güzel Sanatlar Lisesi mezunu, $18^{\prime} i(\% 48,6)$ diğer liselerden mezundur. Trakya Üniversitesi çalışma grubu öğrencilerinin 48'i $(\% 75,0)$ yetenek sınavını kazanmadan önce resim kursu almış, 16'sı $(\% 25,0)$ yetenek sınavını kazanmadan önce resim kursu almamıştır. Abant İzzet Baysal Üniversitesi çalışma grubu öğrencilerinin ise $31^{\prime} \mathrm{i}(\% 83,8)$ yetenek sınavını kazanmadan önce resim kursu almış, 6'sı $(\% 16,2)$ yetenek sınavını kazanmadan önce resim kursu almamıştır. Trakya Üniversitesi çalışma grubu öğrencilerinden resim kursu alanların 20'si (\%41,7) 1-2 ay aralığında, 14'ü $(\% 29,2) 1$ yıl, 14'ü $(\% 29,2) 1$ yıldan fazla; Abant İzzet Baysal Üniversitesi çalışma grubu 
öğrencilerinden resim kursu alanların $15^{\prime} i(\% 51,7) 1-2$ ay aralı̆ı̆ında, 8'i $(\% 27,6) 1$ yıl, 6’sı $(\% 20,7) 1$ yıldan fazla süre kurs almıştır. Trakya Üniversitesi çalışma grubu öğrencilerinin 57'si $(\% 89,1)$ ders dışında resim yapmakta, 7 'i $(\% 10,9)$ ders dışında resim yapmamaktadır. Abant İzzet Baysal Üniversitesi çalışma grubu öğrencilerinin ise 37'si $(\% 100,0)$ ders dışında resim yapmakta, 0 'ı $(\% 0,0)$ ders dışında resim yapmamaktadır. Yani Abant İzzet Baysal Üniversitesi çalışma grubu öğrencilerinin hepsi bir haftalık süreçte ders dışında resim yapmaktadır. Trakya Üniversitesi çalışma grubu öğrencilerinin $25^{\prime} i(\% 41,7)$ haftada 1-2 saat aralığında, $24^{\prime} u ̈(\% 40,0)$ 3-5 saat aralığında, 9'u (\%15,0) 6-10 saat aralı̆ı̆ında, 2'si $(\% 3,3) 11$ ve daha fazla saat ders dışında resim yapmaktadır. Abant İzzet Baysal Üniversitesi çalışma grubu öğrencilerinin ise $15^{\prime} i$ $(\% 40,5)$ haftada 1-2 saat aralığında, 17'si $(\% 45,9)$ 3-5 saat aralığında, 5'u $(\% 13,5)$ 6-10 saat aralığında, 0 'ı $(\% 0,0) 11$ ve daha fazla saat ders dışında resim yapmaktadır.

\subsection{Veri Toplama Araçları}

Araştırmada veri toplama aracı olarak, öğrenci hakkında bilgi toplamak amacıyla "Kişisel Bilgi Formu" ve resimde mekân ile ilgili araştırmacı Aylin Beyoğlu tarafından hazırlanan "Resimde mekân ölçeği" kullanılmıştır. Kişisel Bilgi Formu; cinsiyet, yaş, üniversite, sınıf, mezun olduğu lise, yetenek sınavını kazanmadan önce resim kursu alıp almadığı, resim kursu aldıysa ne kadar zaman aldığı, ders dışında resim yapıp yapmadığı, ders dışında resim yapıyorsa haftada kaç saat yaptığı gibi demografik özelliklerin yer aldığı dokuz sorudan oluşmaktadır.

Resimde mekân ölçeği ise, araştırmacı Aylin Beyoğlu tarafından geliştirilerek uzman görüşleriyle tamamlanmıştır. Resimde mekân ölçeğinin ilk altı sorusu resimde mekân ile ilgili genel bilgileri, yedinci sorudan itibaren ise Resim Anasanat Atölye derslerinde öğrencilerin çalıştığı resimlerine göre bireysel olarak cevaplayacağı soruları içermektedir. Resimde mekân ölçeği, her birinde evet ve hayır şıkkının yer aldığı zorunlu 31 sorudan oluşmaktadır. Resimde mekân ölçeği, 5 alan uzmanı ve 1 dil uzmanı olmak üzere 6 uzman kontrolünde revize edilmiştir.

\subsection{Verilerin Toplanması}

Araştırmanın yürütülebilmesi için öncelikle Trakya Üniversitesi ve Abant İzzet Baysal Üniversitesi Eğitim Fakültesi Güzel Sanatlar Eğitimi Bölümü Resim-iş̧ Eğitimi Anabilim Dallarından verilerin toplanabilmesine dair gerekli izinler alınmıştır. "Kişisel Bilgi Formu" ve "Resimde Mekân Ölçeği" Anasanat Atölye Resim dersinde öğretim elemanlarının uygun gördüğü bir ders saatinde uygulanmıştır.

\subsection{Verilerin Çözümlenmesi}

Araştırmanın bağımsız değişkenlerini Trakya Üniversitesi Eğitim Fakültesi Güzel Sanatlar Eğitimi Bölümü Resim-iş Eğitimi Anabilim Dalı Resim Anasanat Atölye öğrencileri ve Abant İzzet Baysal Üniversitesi Eğitim Fakültesi Güzel Sanatlar Eğitimi Bölümü Resim-iş Eğitimi Anabilim Dalı Resim Anasanat Atölye öğrencileri; cinsiyet, yaş, üniversite, sınıf, mezun olduğu lise, yetenek sınavını kazanmadan önce resim kursu alıp almadığı, resim kursu aldıysa ne kadar zaman aldığı, ders dışında resim yapıp yapmadığı, ders dışında resim yapıyorsa haftada kaç saat yaptığı gibi gibi demografik özellikler oluşturmaktadır. Araştırma verileri değerlendirilirken, veriler betimsel istatistik yoluyla incelenmiş, tanımlayıcı istatistiksel metotların (Frekans, Yüzde, Ortalama, Standart Sapma) yanı sıra niteliksel veriler karşılaştırılmıştır. Resimde mekân kavramı ile ilgili genel bilgilerin maddeler arası içtutarlık güvenirliğini saptamak için maddetoplam korelasyon ve madde-hariç toplam korelasyon katsayıları hesaplanmıştır. Öğrencilerin Anasanat Atölye derslerinde yaptıkları resimlerindeki mekân ile ilgili maddeler arası içtutarlık güvenirliği saptamak için madde-toplam korelasyon ve madde-hariç toplam korelasyon katsayıları hesaplanmıştır. Resimde Mekân Kavramı ile illgili Genel Bilgi ve öğrencilerin 
Anasanat Atölye derslerinde yaptıkları resimlerindeki mekân ile ilgili İçin Ayırtetme Gücü t-Testi sonuçları karşılaştırıımıştır. Çarpıklık ve basıklık bakımından normallik sınaması gösterilmiştir. Betimsel istatistikler ve t-Testi istatistikleri sunulmuştur.

\section{BULGULAR}

Bu bölümde, resimde mekân kavramı ile ilgili madde-toplam korelasyon ve madde-hariç toplam korelasyon katsayıları hesaplanmıştır. Resimde Mekân Kavramı ile ilgili Genel Bilgi ve öğrencilerin Anasanat Atölye derslerinde yaptıkları resimlerindeki mekân ile ilgili ayırt etme gücü t-Testi sonuçları karşılaştııılmıştır. Çarpıklık ve basıklık bakımından normallik sınaması gösterilmiştir. Betimsel istatistikler ve t-Testi istatistikleri sunulmuştur.

Tablo 1

Resimde Mekân Kavramı ile Ilgili Genel Bilgi için Boyutlararası lçtutarlık Analizi

\begin{tabular}{|c|c|c|c|c|c|c|}
\hline \multirow[b]{2}{*}{ soru } & \multicolumn{3}{|c|}{ Madde-toplam korelasyon katsayısı } & \multicolumn{3}{|c|}{ Madde- hariç toplam korelasyon katsayısı } \\
\hline & rit & sd & $\mathbf{p}$ & rir & sd & $\mathbf{p}$ \\
\hline s1 & 0,692 & 97 & $p<.01$ & 0,576 & 97 & $p<.01$ \\
\hline s2 & 0,620 & 99 & $\mathrm{p}<.01$ & 0,473 & 99 & $\mathrm{p}<.01$ \\
\hline s3 & 0,640 & 99 & $\mathrm{p}<.01$ & 0,391 & 99 & $\mathrm{p}<.01$ \\
\hline s4 & 0,641 & 99 & $\mathrm{p}<.01$ & 0,476 & 99 & $\mathrm{p}<.01$ \\
\hline s5 & 0,549 & 99 & $\mathrm{p}<.01$ & 0,388 & 99 & $\mathrm{p}<.01$ \\
\hline \multirow[t]{3}{*}{ s6 } & 0,665 & 97 & $p<.01$ & 0,315 & 97 & $p<.01$ \\
\hline & rulon & & & cronbach & & \\
\hline & 0,673 & & & 0,678 & & \\
\hline
\end{tabular}

Tablo 1'de görüldüğü gibi, resimde mekân kavramı ile ilgili genel bilgilerin maddeler arası içtutarlık güvenirliğini saptamak için madde-toplam korelasyon ve madde-hariç toplam korelasyon katsayıları hesaplanmıştır. Madde ortalamalarının boyut ortalamasıyla ilişkilerini sorgulamak için hesaplanan Rulon $=0.673$, Croanbach $a=0.678$ olarak bulunmuştur. Bu analizlere göre tüm maddelerin resimde mekân kavramı ile ilgili genel bilgi ölçeği toplamı ile pozitif yönde ve içtutarlık gösterdiği görülmüştür. 
Tablo 2

Resimde Mekân İçin Boyutlararası lç̧tutarlık Analizi

\begin{tabular}{|c|c|c|c|c|c|c|}
\hline \multirow[b]{2}{*}{ soru } & \multicolumn{3}{|c|}{ Madde-toplam korelasyon katsayısı } & \multicolumn{3}{|c|}{ Madde- hariç toplam korelasyon katsayısı } \\
\hline & rit & sd & $\mathbf{p}$ & rir & sd & p \\
\hline s7 & 0,382 & 98 & $\mathrm{p}<.01$ & 0,315 & 98 & $p<.01$ \\
\hline s8 & 0,533 & 99 & $\mathrm{p}<.01$ & 0,465 & 99 & $p<.01$ \\
\hline s9 & 0,604 & 99 & $\mathrm{p}<.01$ & 0,534 & 99 & $p<.01$ \\
\hline s10 & 0,317 & 99 & $\mathrm{p}<.01$ & 0,252 & 99 & $p<.05$ \\
\hline s11 & 0,404 & 99 & $\mathrm{p}<.01$ & 0,317 & 99 & $\mathrm{p}<.01$ \\
\hline s12 & 0,637 & 99 & $p<.01$ & 0,571 & 99 & $p<.01$ \\
\hline s13 & 0,368 & 97 & $p<.01$ & 0,275 & 97 & $p<.01$ \\
\hline s14 & 0,476 & 99 & $p<.01$ & 0,392 & 99 & $p<.01$ \\
\hline s15 & 0,462 & 99 & $p<.01$ & 0,376 & 99 & $p<.01$ \\
\hline s16 & 0,319 & 99 & $p<.01$ & 0,237 & 99 & $p<.05$ \\
\hline s17 & 0,322 & 98 & $p<.01$ & 0,231 & 98 & $p<.05$ \\
\hline s18 & 0,342 & 99 & $p<.01$ & 0,263 & 99 & $p<.01$ \\
\hline s19 & 0,504 & 98 & $p<.01$ & 0,423 & 98 & $p<.01$ \\
\hline s20 & 0,358 & 99 & $p<.01$ & 0,272 & 99 & $p<.01$ \\
\hline s21 & 0,548 & 99 & $p<.01$ & 0,472 & 99 & $p<.01$ \\
\hline s22 & 0,445 & 99 & $p<.01$ & 0,367 & 99 & $p<.01$ \\
\hline s23 & 0,422 & 98 & $p<.01$ & 0,339 & 98 & $p<.01$ \\
\hline s24 & 0,398 & 99 & $p<.01$ & 0,306 & 99 & $p<.01$ \\
\hline$s 25$ & 0,364 & 99 & $p<.01$ & 0,272 & 99 & $p<.01$ \\
\hline s26 & 0,387 & 98 & $p<.01$ & 0,306 & 98 & $p<.01$ \\
\hline s27 & 0,258 & 99 & $p<.01$ & 0,174 & 99 & $*$ \\
\hline s28 & 0,562 & 98 & $p<.01$ & 0,490 & 98 & $p<.01$ \\
\hline$s 29$ & 0,318 & 99 & $p<.01$ & 0,238 & 99 & $p<.05$ \\
\hline s30 & 0,465 & 98 & $p<.01$ & 0,384 & 98 & $p<.01$ \\
\hline \multirow[t]{3}{*}{ s31 } & 0,352 & 99 & $p<.01$ & 0,258 & 99 & $p<.01$ \\
\hline & rulon & & & cronbach & & \\
\hline & 0,765 & & & 0,809 & & \\
\hline
\end{tabular}

Tablo 2'de görüldüğü gibi, öğrencilerin Anasanat Atölye derslerinde yaptıkları resimlerindeki mekân ile ilgili maddeler arası içtutarlık güvenirliği saptamak için madde-toplam korelasyon ve madde-hariç toplam korelasyon katsayıları hesaplanmıştır. Madde ortalamalarının boyut ortalamasıyla ilişkilerini sorgulamak için hesaplanan Rulon=0.765, Croanbach a=0.809 olarak bulunmuştur. Bu analizlere göre tüm maddelerin Resimde Mekân ölçeği toplamı ile pozitif yönde ve içtutarlık gösterdiği görülmüştür.

Tablo 3

Resimde Mekân Kavramı Ile Illgili Genel Bilgi İçin Ayırtetme Gücü t-Testi Sonuçları

\begin{tabular}{ccccccccccc}
\hline & \multicolumn{4}{c}{ Üst Çeyreklik } & \multicolumn{4}{c}{ Alt Çeyreklik } & \multicolumn{3}{c}{ Karşılaştırma } \\
\hline soru & $\mathbf{n}$ & $\bar{x}$ & ss & $\mathbf{n}$ & $\bar{x}$ & ss & t & sd & p \\
\hline s1 & 27 & 1,000 & 0,000 & 25 & 0,800 & 0,408 & 2,400 & 50 & $\mathrm{p}<.01$ & 0,007 \\
s2 & 27 & 1,000 & 0,000 & 27 & 0,778 & 0,424 & 2,675 & 52 & $\mathrm{p}<.01$ & 0,004 \\
s3 & 27 & 1,000 & 0,000 & 27 & 0,519 & 0,509 & 4,822 & 52 & $\mathrm{p}<.01$ & 0,000 \\
s4 & 27 & 1,000 & 0,000 & 27 & 0,741 & 0,447 & 2,960 & 52 & $\mathrm{p}<.01$ & 0,002 \\
s5 & 27 & 1,000 & 0,000 & 27 & 0,815 & 0,396 & 2,385 & 52 & $\mathrm{p}<.05$ & 0,009 \\
s6 & 27 & 1,000 & 0,000 & 26 & 0,077 & 0,272 & 16,984 & 51 & $\mathrm{p}<.01$ & 0,000 \\
\hline
\end{tabular}

Tablo 3'te görüldüğü gibi, öğrencilerin resimde mekân kavramı ile ilgili genel bilgi için yüksek düzeyde bilgiye sahip kişiler ile düşük düzeyde bilgiye sahip kişileri ayırt etme gücünü 
saptamak için üst çeyreklikteki kişiler ile alt çeyreklikteki kişiler arasında fark olup olmadığını analiz etmeye yönelik t-Testi kullanılmıştır. Maddelerin ölçek toplamına göre oluşturulan çeyreklikler arasındaki farkını sorgulamak için hesaplanan t-Testi sonuçlarına göre tüm maddelerin ölçeğin toplamına göre yüksek ve düşük bilgi düzeyindeki düzeyindeki kişileri ayırt etmeye hizmet ettiği görülmüştür.

Tablo 4

Resimde Mekân İçin Ayırtetme Gücü t-Testi Sonuçları

\begin{tabular}{ccccccccccc}
\hline & \multicolumn{3}{c}{ Üst Çeyreklik } & \multicolumn{3}{c}{ Alt Çeyreklik } & \multicolumn{3}{c}{ Karşıllaştırma } \\
\hline soru & $\mathbf{n}$ & $\bar{x}$ & ss & $\mathbf{n}$ & $\bar{x}$ & ss & t & sd & p \\
\hline s7 & 27 & 0,963 & 0,192 & 27 & 0,630 & 0,492 & 3,217 & 52 & $\mathrm{p}<.01$ & 0,001 \\
s8 & 27 & 0,963 & 0,192 & 27 & 0,370 & 0,492 & 5,719 & 52 & $\mathrm{p}<.01$ & 0,000 \\
s9 & 27 & 0,926 & 0,267 & 27 & 0,185 & 0,396 & 7,912 & 52 & $\mathrm{p}<.01$ & 0,000 \\
s10 & 27 & 0,889 & 0,320 & 27 & 0,667 & 0,480 & 1,963 & 52 & $\mathrm{p}<.05$ & 0,025 \\
s11 & 27 & 0,963 & 0,192 & 27 & 0,444 & 0,506 & 4,881 & 52 & $\mathrm{p}<.01$ & 0,000 \\
s12 & 27 & 0,963 & 0,192 & 27 & 0,111 & 0,320 & 11,625 & 52 & $\mathrm{p}<.01$ & 0,000 \\
s13 & 27 & 0,741 & 0,447 & 26 & 0,192 & 0,402 & 4,613 & 51 & $\mathrm{p}<.01$ & 0,000 \\
s14 & 27 & 0,815 & 0,396 & 27 & 0,222 & 0,424 & 5,211 & 52 & $\mathrm{p}<.01$ & 0,000 \\
s15 & 27 & 0,815 & 0,396 & 27 & 0,185 & 0,396 & 5,735 & 52 & $\mathrm{p}<.01$ & 0,000 \\
s16 & 27 & 0,926 & 0,267 & 27 & 0,593 & 0,501 & 2,996 & 52 & $\mathrm{p}<.01$ & 0,002 \\
s17 & 27 & 0,889 & 0,320 & 27 & 0,444 & 0,506 & 3,782 & 52 & $\mathrm{p}<.01$ & 0,000 \\
s18 & 27 & 0,926 & 0,267 & 27 & 0,556 & 0,506 & 3,299 & 52 & $\mathrm{p}<.01$ & 0,001 \\
s19 & 27 & 0,926 & 0,267 & 27 & 0,259 & 0,447 & 6,534 & 52 & $\mathrm{p}<.01$ & 0,000 \\
s20 & 27 & 0,889 & 0,320 & 27 & 0,481 & 0,509 & 3,454 & 52 & $\mathrm{p}<.01$ & 0,000 \\
s21 & 27 & 0,815 & 0,396 & 27 & 0,148 & 0,362 & 6,337 & 52 & $\mathrm{p}<.01$ & 0,000 \\
s22 & 27 & 0,963 & 0,192 & 27 & 0,444 & 0,506 & 4,881 & 52 & $\mathrm{p}<.01$ & 0,000 \\
s23 & 27 & 0,667 & 0,480 & 27 & 0,111 & 0,320 & 4,907 & 52 & $\mathrm{p}<.01$ & 0,000 \\
s24 & 27 & 0,815 & 0,396 & 27 & 0,370 & 0,492 & 3,588 & 52 & $\mathrm{p}<.01$ & 0,000 \\
s25 & 27 & 0,778 & 0,424 & 27 & 0,370 & 0,492 & 3,199 & 52 & $\mathrm{p}<.01$ & 0,001 \\
s26 & 26 & 0,885 & 0,326 & 27 & 0,556 & 0,506 & 2,770 & 51 & $\mathrm{p}<.01$ & 0,004 \\
s27 & 27 & 0,370 & 0,492 & 27 & 0,148 & 0,362 & 1,855 & 52 & $\mathrm{p}<.05$ & 0,032 \\
s28 & 26 & 0,962 & 0,196 & 27 & 0,259 & 0,447 & 7,318 & 51 & $\mathrm{p}<.01$ & 0,000 \\
s29 & 27 & 0,852 & 0,362 & 27 & 0,519 & 0,509 & 2,721 & 52 & $\mathrm{p}<.01$ & 0,004 \\
s30 & 27 & 0,593 & 0,501 & 26 & 0,077 & 0,272 & 4,595 & 51 & $\mathrm{p}<.01$ & 0,000 \\
s31 & 27 & 0,741 & 0,447 & 27 & 0,296 & 0,465 & 3,514 & 52 & $\mathrm{p}<.01$ & 0,000 \\
\hline
\end{tabular}

Tablo 4'te görüldüğü gibi, öğrencilerin Anasanat Atölye derslerinde yaptıkları resimlerindeki mekân ile ilgili olumlu tutuma sahip kişiler ile olumsuz tutuma sahip kişileri ayırt etme gücünü saptamak için üst çeyreklikteki kişiler ile alt çeyreklikteki kişiler arasında fark olup olmadığını analiz etmeye yönelik t-Testi kullanılmıştır. Maddelerin ölçek toplamına göre oluşturulan çeyreklikler arasındaki farkını sorgulamak için hesaplanan t-Testi sonuçlarına göre tüm maddelerin ölçeğin toplamına göre olumlu ve olumsuz tutuma sahip kişileri ayırt etmeye hizmet ettiği görülmüştür. 
Tablo 5

Çarpıklık ve Basıklık Bakımından Normallik Sınaması

\begin{tabular}{lccrrrrr}
\hline & & \multicolumn{1}{c}{ Skewness (Çarpıklık) } & \multicolumn{2}{c}{ Kurtosis (Basıklık) } \\
\hline & $\mathbf{n}$ & $\bar{x}$ & ss & Katsayı & $\mathbf{- 0 , 3 9 9}$ & Katsayı & Std.Hata \\
\hline Toplam Yaşam Kalitesi & 101 & 0,857 & 0,197 & $-2,288$ & 0,240 & 6,878 & 0,476 \\
Toplam Yaşam Kalitesi & 101 & 0,605 & 0,197 & $-0,192$ & 0,240 & $-0,625$ & 0,476 \\
\hline
\end{tabular}

Tablo 5'te görüldüğü gibi, araştırma verilerinin normal dağılım gösterdiğini ortaya koymaktadır.

Tablo 6

Resimde Mekân Kavramı ile Ilgili Genel Bilgi Için Betimsel Istatistikler

\begin{tabular}{|c|c|c|c|}
\hline soru & $\mathbf{n}$ & $\bar{x}$ & ss \\
\hline Mekân kavramının tanımını biliyorum. & 99 & 0,949 & 0,220 \\
\hline $\begin{array}{l}\text { Mekân kavramını oluşturan elemanları } \\
\text { biliyorum. }\end{array}$ & 101 & 0,941 & 0,238 \\
\hline $\begin{array}{l}\text { Mekân kavramını etkileyen faktörleri } \\
\text { biliyorum. }\end{array}$ & 101 & 0,832 & 0,376 \\
\hline $\begin{array}{l}\text { Sanat eserlerindeki mekânları kolay } \\
\text { algılayabiliyorum. }\end{array}$ & 101 & 0,921 & 0,271 \\
\hline $\begin{array}{l}\text { Sanat eserlerindeki mekânı diğer öğelerden } \\
\text { ayırt edebiliyorum. }\end{array}$ & 101 & 0,941 & 0,238 \\
\hline $\begin{array}{l}\text { Sanatçıların eserlerindeki mekânları sanat } \\
\text { akımlarına göre ayırt edebiliyorum. }\end{array}$ & 99 & 0,556 & 0,499 \\
\hline Resimde mekân kavramı ile ilgili genel bilgi & 101 & 0,857 & 0,197 \\
\hline
\end{tabular}

Tablo 6'da görüldüğü gibi, resimde mekân kavramı ile ilgili genel bilgi için betimsel istatistikler sunulmuştur. Öğrencilerin resimde mekân kavramı ile ilgili genel bilgi için tutumları içinde en yüksek düzeyde (olumlu) olanları mekân kavramının tanımını biliyorum $(=0,949)$, mekân kavramını oluşturan elemanları biliyorum $(=0,941)$, sanat eserlerindeki mekânı diğer öğelerden ayırt edebiliyorum $(=0,941)$ ve sanat eserlerindeki mekânları kolay algılayabiliyorum $(=0,921)$, en düşük düzeyde (olumsuz) olanı sanatçıların eserlerindeki mekânları sanat akımlarına göre ayırt edebiliyorum ( $=0,556)$ boyutlarıdır.

Öğrencilerin resimde mekân kavramı ile ilgili genel bilgi için tutumları içinde en homojen tutumda olanları mekân kavramının tanımını biliyorum $(s s=0,220)$, mekân kavramını oluşturan elemanları biliyorum $(s s=0,238)$ ve sanat eserlerindeki mekânı diğer öğelerden ayırt edebiliyorum (ss=0,238), en heterojen olanı ise sanatçıların eserlerindeki mekânları sanat akımlarına göre ayırt edebiliyorum $(s s=0,499)$ boyutlarıdır. 
Tablo 7

Resimde Mekân Tutumu İçin Betimsel Istatistikler

\begin{tabular}{|c|c|c|c|}
\hline soru & $\mathbf{n}$ & $\bar{x}$ & ss \\
\hline Mekânı kurgulayarak oluşturuyorum. & 100 & 0,840 & 0,368 \\
\hline Mekânı önemsiyorum. & 101 & 0,743 & 0,439 \\
\hline Mekânı oluştururken sorun yaşıyorum. & 101 & 0,594 & 0,494 \\
\hline Mekânı sadece boşluk olarak kullanıyorum. & 101 & 0,861 & 0,347 \\
\hline Mekânı oluştururken sıkıntı yaşıyorum. & 101 & 0,653 & 0,478 \\
\hline Mekân oluşturmayı seviyorum. & 101 & 0,594 & 0,494 \\
\hline Mekânı oluşturmak çok zamanımı alıyor. & 99 & 0,485 & 0,502 \\
\hline $\begin{array}{l}\text { Mekânı özen göstermeden hızlıca } \\
\text { yapıyorum. }\end{array}$ & 101 & 0,594 & 0,494 \\
\hline Mekânı çok düşünerek yapıyorum. & 101 & 0,515 & 0,502 \\
\hline Mekân oluşturmak istiyorum. & 101 & 0,762 & 0,428 \\
\hline Mekânı figür ile oluşturmayı seviyorum. & 100 & 0,650 & 0,479 \\
\hline $\begin{array}{l}\text { Mekânı nesneler ile oluşturmayı } \\
\text { seviyorum. }\end{array}$ & 101 & 0,772 & 0,421 \\
\hline İç mekân oluşturmayı seviyorum. & 100 & 0,590 & 0,494 \\
\hline Dış mekân oluşturmayı seviyorum. & 101 & 0,693 & 0,464 \\
\hline $\begin{array}{l}\text { İç ve dış mekânı birlikte oluşturmayı } \\
\text { seviyorum. }\end{array}$ & 101 & 0,406 & 0,494 \\
\hline Gerçek mekânlar yapmayı seviyorum. & 101 & 0,723 & 0,450 \\
\hline Mimari mekânlar çalışmayı seviyorum. & 100 & 0,320 & 0,469 \\
\hline Kent görünümlerini çalışmayı seviyorum. & 101 & 0,495 & 0,502 \\
\hline Köy görünümlerini çalışmayı seviyorum. & 101 & 0,594 & 0,494 \\
\hline Sokak görünümlerini çalışmayı seviyorum. & 100 & 0,730 & 0,446 \\
\hline $\begin{array}{l}\text { Mekânı ders } \\
\text { bilgisayar programinda ya da sonrasında } \\
\text { seviyorum. }\end{array}$ & 101 & 0,238 & 0,428 \\
\hline Yaptığım mekânları beğeniyorum. & 100 & 0,660 & 0,476 \\
\hline $\begin{array}{l}\text { Mekânı modelle ilişkilendirerek } \\
\text { kullanıyorum. }\end{array}$ & 101 & 0,772 & 0,421 \\
\hline $\begin{array}{l}\text { Atölye dersinde mekân kavramı ile ilgili } \\
\text { verilen bilgiyi yeterli görüyorum. }\end{array}$ & 100 & 0,330 & 0,473 \\
\hline $\begin{array}{l}\text { Atölye dersinde mekân kavramı ile ilgili } \\
\text { verilen bilgiyi } \\
\text { pekiştirebiliyorum. }\end{array}$ & 101 & 0,515 & 0,502 \\
\hline resimde mekân & 101 & 0,605 & 0,197 \\
\hline
\end{tabular}

Tablo 7'de görüldüğü gibi, Anasanat Atölye dersi resim öğrencilerinin resimde mekân tutumu ile ilgili betimsel istatistikler sunulmuştur. Öğrencilerin resimde mekân tutumları içinde en yüksek düzeyde (olumlu) olanları mekânı sadece boşluk olarak kullanıyorum $(=0,861)$, mekânı kurgulayarak oluşturuyorum $(=0,840)$, mekânı nesneler ile oluşturmayı seviyorum ( $=0,772)$, ve mekânı modelle ilişkilendirerek kullanıyorum $(=0,772)$, mekân oluşturmak istiyorum $(=0,762)$, mekânı önemsiyorum $(=0,743)$, sokak görünümlerini çalışmayı seviyorum ( 
$=0,730$ ) ve gerçek mekânlar yapmayı seviyorum $(=0,723)$ en düşük düzeyde (olumsuz) olanları ise; mekânı ders öncesinde ya da sonrasında bilgisayar programında tasarlamayı seviyorum ( $=0,238)$, mimari mekânlar çalışmayı seviyorum $(=0,320)$, atölye dersinde mekân kavramı ile ilgili verilen bilgiyi yeterli görüyorum ( $=0,330$ ), iç ve dış mekânı birlikte oluşturmayı seviyorum ( $=0,406)$, mekânı oluşturmak çok zamanımı alıyor $(=0,485)$, kent görünümlerini çalışmayı seviyorum $(=0,495)$ boyutlarıdır.

Öğrencilerin resimde mekân tutumları içinde en homojen tutumda olanları Mekânı sadece boşluk olarak kullanıyorum $(s s=0,347)$ ve mekânı kurgulayarak oluşturuyorum (ss=0,368), en heterojen olanları ise; mekânı oluşturmak çok zamanımı alıyor (ss=0,502), mekânı çok düşünerek yapıyorum $(s s=0,502)$, kent görünümlerini çalışmayı seviyorum $(s s=0,502)$, atölye dersinde mekân kavramı ile ilgili verilen bilgiyi örneklerle pekiştirebiliyorum $(s s=0,502)$, mekânı oluştururken sorun yaşıyorum $(s s=0,494)$, mekân oluşturmayı seviyorum $(s s=0,494)$, mekânı özen göstermeden hızlıca yapıyorum $(s s=0,494)$, iç mekân oluşturmayı seviyorum $(s s=0,494)$, iç ve dış mekânı birlikte oluşturmayı seviyorum $(s s=0,494)$, köy görünümlerini çalışmayı seviyorum $(s s=0,494)$ boyutlarıdır.

Tablo 8

Öğrencinin Cinsiyeti Değişkenine Göre Resimde Mekân Değişkeni Iç̧in t-Testi Istatistikleri

\begin{tabular}{|c|c|c|c|c|c|c|c|}
\hline & & $\mathbf{n}$ & $\bar{x}$ & SS & $\mathbf{t}$ & sd & $\mathbf{p}$ \\
\hline \multirow{4}{*}{$\begin{array}{l}\text { Resimde mekân kavramı ile ilgili } \\
\text { genel bilgi } \\
\text { resimde mekân }\end{array}$} & KIz & 80 & 0,878 & 0,160 & 2,108 & 99 & 0,038 \\
\hline & Erkek & 21 & 0,778 & 0,290 & & & \\
\hline & KIz & 80 & 0,582 & 0,186 & $-2,336$ & 99 & 0,021 \\
\hline & Erkek & 21 & 0,692 & 0,215 & & & \\
\hline
\end{tabular}

Tablo 8'de görüldüğü gibi, Anasanat Atölye dersi resim öğrencilerinin resimde mekân kavramı ile ilgili genel bilgileri $(t=2,108 s d=99 p=0,038)$ ve resimlerinde mekân tutumları $(t=-$ 2,336 sd=99 $p=0,021)$ onların cinsiyetine göre farklılık göstermektedir. Kız öğrencilerin ( $=0,878)$ resimde mekân kavramı ile ilgili genel bilgileri erkek öğrencilere $(=0,778)$ göre daha yüksektir. Kız öğrencilerin $(=0,582)$ resimlerinde mekân tutumları erkek öğrencilere $(=0,692)$ göre daha düşüktür.

Tablo 9

Öğrencinin okumakta olduğu üniversite Değişkenine Göre Resimde Mekân Değişkeni için t-Testi istatistikleri

\begin{tabular}{|c|c|c|c|c|c|c|c|}
\hline & & $\mathrm{n}$ & $\bar{x}$ & ss & $\mathbf{t}$ & sd & p \\
\hline \multirow{2}{*}{$\begin{array}{l}\text { Resimde mekân kavramı ile ilgili } \\
\text { genel bilgi }\end{array}$} & Trakya Üniversitesi & 64 & 0,876 & 0,189 & \multirow[t]{2}{*}{1,271} & \multirow[t]{2}{*}{99} & \multirow[t]{2}{*}{0,207} \\
\hline & $\begin{array}{l}\text { Abant İzzet Baysal } \\
\text { Üniversitesi }\end{array}$ & 37 & 0,824 & 0,208 & & & \\
\hline \multirow[t]{2}{*}{ resimde mekân } & Trakya Üniversitesi & 64 & 0,574 & 0,195 & \multirow[t]{2}{*}{$-2,136$} & \multirow[t]{2}{*}{99} & \multirow[t]{2}{*}{0,035} \\
\hline & $\begin{array}{l}\text { Abant İzzet Baysal } \\
\text { Üniversitesi }\end{array}$ & 37 & 0,659 & 0,190 & & & \\
\hline
\end{tabular}

Tablo 9'da görüldüğü gibi, Anasanat Atölye dersi resim öğrencilerinin resimde mekân kavramı ile ilgili genel bilgileri $(t=1,271 s d=99 p=0,207)$ onların okumakta olduğu üniversite değişkenine göre farklılık göstermemektedir. Anasanat Atölye dersi resim öğrencilerinin resimde mekân tutumları ( $t=-2,136 \mathrm{sd}=99 \mathrm{p}=0,035)$ onların okumakta olduğu üniversite değişkenine göre farklılık göstermektedir. Abant İzzet Baysal Üniversitesi öğrencilerinin ( $=0,659)$ resimlerinde mekân tutumları Trakya Üniversitesi öğrencilerine $(=0,574)$ göre daha olumludur. 
Tablo 10

Öğrencinin Mezun Olduğu Lise Değişkenine Göre Resimde Mekân Değişkeni Için t-Testi Istatistikleri

\begin{tabular}{|c|c|c|c|c|c|c|c|}
\hline & & $\mathrm{n}$ & $\bar{x}$ & ss & $\mathbf{t}$ & sd & $p$ \\
\hline \multirow{4}{*}{$\begin{array}{l}\text { Resimde mekân kavramı ile ilgili } \\
\text { genel bilgi } \\
\text { resimde mekân }\end{array}$} & Güzel Sanatlar Lisesi & 40 & 0,899 & 0,125 & 1,766 & 99 & 0,080 \\
\hline & Diğer liseler & 61 & 0,829 & 0,229 & & & \\
\hline & Güzel Sanatlar Lisesi & 40 & 0,640 & 0,181 & 1,448 & 99 & 0,151 \\
\hline & Diğer liseler & 61 & 0,582 & 0,204 & & & \\
\hline
\end{tabular}

Tablo 10'da görüldüğü gibi, Anasanat Atölye dersi resim öğrencilerinin resimde mekân kavramı ile ilgili genel bilgileri $(t=1,766 \mathrm{sd}=99 \mathrm{p}=0,080)$ ve resimlerinde mekân tutumları ( $t=-$ $1,448 \mathrm{sd}=99 \mathrm{p}=0,151$ ) onların mezun olduğu lise değişkenine göre farklılık göstermemektedir.

Tablo 11

Öğrencinin Yetenek Sınavını Kazanmadan Önce Resim Kursu Alıp Almadığı Değişkenine Göre Resimde Mekân Değişkeni Için t-Testi İstatistikleri

\begin{tabular}{llcccccc}
\hline & & $\mathbf{n}$ & $\bar{x}$ & ss & t & sd & p \\
\hline Resimde mekân kavramı ile ilgili & Evet & 79 & 0,853 & 0,192 & $-0,343$ & 99 & 0,733 \\
genel bilgi & Hayır & 22 & 0,870 & 0,218 & & & \\
resimde mekân & Evet & 79 & 0,607 & 0,206 & 0,166 & 99 & 0,868 \\
& Hayır & 22 & 0,599 & 0,162 & & & \\
\hline
\end{tabular}

Tablo 11'de görüldüğü gibi, Anasanat Atölye dersi resim öğrencilerinin resimde mekân kavramı ile ilgili genel bilgileri $(t=-0,343 \mathrm{sd}=99 \mathrm{p}=0,733)$ ve resimde mekân tutumları $(\mathrm{t}=-0,166$ $\mathrm{sd}=99 \mathrm{p}=0,868$ ) onların yetenek sınavını kazanmadan önce resim kursu alıp almadığı değişkenine göre farklılık göstermemektedir.

Tablo 12

Öğrencinin Ders Dışında Resim Yapıp Yapmadığı Değişkenine Göre Resimde Mekân Değişkeni Için t-Testi istatistikleri

\begin{tabular}{|c|c|c|c|c|c|c|c|}
\hline & & $\mathrm{n}$ & $\bar{x}$ & ss & $t$ & $s d$ & $p$ \\
\hline \multirow{4}{*}{$\begin{array}{l}\text { Resimde mekân kavramı ile ilgili } \\
\text { genel bilgi } \\
\text { resimde mekân }\end{array}$} & Evet & 94 & 0,852 & 0,202 & $-0,999$ & 99 & 0,320 \\
\hline & Hayır & 7 & 0,929 & 0,089 & & & \\
\hline & Evet & 94 & 0,615 & 0,185 & 1,933 & 99 & 0,056 \\
\hline & Hayır & 7 & 0,469 & 0,297 & & & \\
\hline
\end{tabular}

Tablo 12'de görüldüğü gibi, Anasanat Atölye dersi resim öğrencilerinin resimde mekân kavramı ile ilgili genel bilgileri $(t=-0,999 \mathrm{sd}=99 \mathrm{p}=0,320)$ ve resimde mekân tutumları ( $t=-1,933$ $s d=99 p=0,056)$ onların ders dışında resim yapıp yapmadığı değişkenine göre farklılık göstermemektedir.

Tablo 13

Yaşam Kalitesi Iç̧in Varyansların Homojenliği Testi

\begin{tabular}{lcrrr}
\hline & Levene & & & \\
& Statistic & sd1 & sd2 & p \\
\hline Resimde mekân kavramı ile ilgili genel bilgi & 0,215 & 2 & 98 & 0,807 \\
resimde mekân & 1,160 & 2 & 98 & 0,318 \\
\hline
\end{tabular}

Tablo 13'te görüldüğü gibi, Resimde mekân bilgi ve tutumları için varyansların homojenliğini test etmek için Levene istatistiği uygulanmış ve homojen olduğu görülmüştür. Bu sonuca göre ilgili karşılaştırma istatistiklerinde parametrik teknikler kullanılmıştır. 
Tablo 14

Öğrencinin Yaşı Değişkenine Göre Resimde Mekân Için ANOVA Testi Betimsel İstatistikleri

\begin{tabular}{llccc}
\hline & & $\mathbf{n}$ & $\bar{x}$ & ss \\
\hline Resimde mekân & 19 ve daha küçük & 13 & 0,872 & 0,139 \\
kavramı ile ilgili genel & $20-21$ & 57 & 0,872 & 0,159 \\
bilgi & $22-24$ & 24 & 0,847 & 0,245 \\
& 25 ve üstü & 7 & 0,738 & 0,345 \\
resimde mekân & Total & 101 & 0,857 & 0,197 \\
& 19 ve daha küçük & 13 & 0,647 & 0,224 \\
& $20-21$ & 57 & 0,595 & 0,184 \\
& $22-24$ & 24 & 0,582 & 0,221 \\
& 25 ve üstü & 7 & 0,689 & 0,159 \\
& Total & 101 & 0,605 & 0,197 \\
\hline
\end{tabular}

Tablo 14'te görüldüğü gibi, öğrencinin yaşı değişkenine göre resimde mekân için betimsel istatistikler gösterilmiştir.

Tablo 15

Öğrencinin Yaşı Değişkenine Göre Resimde Mekân Için ANOVA İstatistikleri

\begin{tabular}{llrrrrr}
\hline & & \multicolumn{5}{c}{ Kareler } \\
Resimde mekân & Gruplar arası & Kareler Toplamı & sd & Ortalaması & F & p \\
kavramı ile ilgili & Gruplar içi & 0,117 & 3 & 0,039 & 1,011 & 0,391 \\
genel bilgi & Toplam & 3,751 & 97 & 0,039 & & \\
resimde mekân & Gruplar arası & 3,868 & 100 & & & \\
& Gruplar içi & 0,090 & 3 & 0,030 & 0,775 & 0,510 \\
& Toplam & 3,772 & 97 & 0,039 & & \\
\hline
\end{tabular}

Tablo 15'te görüldüğü gibi, öğrencilerin resimde mekân kavramı ile ilgili genel bilgileri ( $F=1,011 s d=3-97 p=0,391)$ ve resimlerinde mekân tutumları ( $F=0,775 s d=3-97 p=0,510)$ onların yaşlarına göre farklılık göstermemektedir.

Tablo 16

Öğrencinin Sınıfı Değişkenine Göre Resimde Mekân Içcin ANOVA Testi Betimsel İstatistikleri

\begin{tabular}{llccc}
\hline & & $\mathbf{n}$ & $\bar{x}$ & ss \\
\hline Resimde mekân & 2. ınıf & 34 & 0,823 & 0,228 \\
kavramı ile ilgili genel & 3.sınıf & 32 & 0,878 & 0,150 \\
bilgi & 4. ınıf & 35 & 0,871 & 0,202 \\
& Total & 101 & 0,857 & 0,197 \\
resimde mekân & 2.sınıf & 34 & 0,581 & 0,209 \\
& 3.sınıf & 32 & 0,638 & 0,178 \\
& 4.sınıf & 35 & 0,599 & 0,202 \\
& Total & 101 & 0,605 & 0,197 \\
\hline
\end{tabular}

Tablo 16'da görüldüğü gibi, öğrencinin sınıfı değişkenine göre resimde mekân için betimsel istatistikler gösterilmiştir. 
Tablo 17

Öğrencinin Sınıfı Değişkenine Göre Resimde Mekân İçin ANOVA Istatistikleri

\begin{tabular}{llrrrrr}
\hline & & \multicolumn{3}{c}{ Kareler } \\
& & Kareler Toplamı & sd & Ortalaması & F & p \\
\hline Resimde mekân & Gruplar arası & 0,061 & 2 & 0,031 & 0,788 & 0,458 \\
kavramı ile ilgili & Gruplar içi & 3,807 & 98 & 0,039 & & \\
genel bilgi & Toplam & 3,868 & 100 & & & \\
\multirow{2}{*}{ resimde mekân } & Gruplar arası & 0,056 & 2 & 0,028 & 0,716 & 0,491 \\
& Gruplar içi & 3,807 & 98 & 0,039 & & \\
& Toplam & 3,862 & 100 & & & \\
\hline
\end{tabular}

Tablo 17'de görüldüğü gibi, öğrencilerin resimde mekân kavramı ile ilgili genel bilgileri $(F=0,788 s d=2-98 p=0,458)$ ve resimlerinde mekân tutumları $(F=0,716 s d=2-98 p=0,491)$ onların sınıfı değişkenine göre farklılık göstermemektedir.

Tablo 18

Öğrencinin Ne Kadar Zamandır Resim Kursu Aldığı Değişkenine Göre Resimde Mekân İçin ANOVA Testi Betimsel istatistikleri

\begin{tabular}{lllll}
\hline & & $\mathbf{n}$ & $\bar{x}$ & ss \\
\hline Resimde mekân & $1-2$ ay & 35 & 0,862 & 0,216 \\
kavramı ile ilgili genel & 1 yıl & 22 & 0,890 & 0,124 \\
bilgi & 1 yıldan fazla & 20 & 0,800 & 0,207 \\
& Total & 77 & 0,854 & 0,192 \\
resimde mekân & $1-2$ ay & 35 & 0,640 & 0,229 \\
& 1 yıl & 22 & 0,580 & 0,170 \\
& 1 yıldan fazla & 20 & 0,561 & 0,200 \\
& Total & 77 & 0,602 & 0,207 \\
\hline
\end{tabular}

Tablo 18'de görüldüğü gibi, öğrencinin ne kadar zamandır resim kursu aldığı değişkenine göre resimde mekân için betimsel istatistikler gösterilmiştir.

Tablo 19

Öğrencinin Ne Kadar Zamandır Resim Kursu Aldığı Değişkenine Göre Resimde Mekân İçin ANOVA istatistikleri

\begin{tabular}{llcrrrr}
\hline & & \multicolumn{3}{c}{ Kareler } \\
& & Kareler Toplamı & sd & Ortalaması & F & p \\
\hline Resimde mekân & Gruplar arası & 0,089 & 2 &, 045 & 1,215 & 0,303 \\
kavramı ile ilgili & Gruplar içi & 2,718 & 74 &, 037 & & \\
genel bilgi & Toplam & 2,808 & 76 & & & \\
\multirow{2}{*}{ resimde mekân } & Gruplar arası & 0,096 & 2 &, 048 & 1,129 & 0,329 \\
& Gruplar içi & 3,151 & 74 &, 043 & & \\
& Toplam & 3,247 & 76 & & & \\
\hline
\end{tabular}

Tablo 19'da görüldüğü gibi, öğrencilerin resimde mekân kavramı ile ilgili genel bilgileri $(F=1,215 s d=2-98 p=0,303)$ ve resimlerinde mekân tutumları ( $F=1,129 s d=2-98 p=0,329)$ onların ne kadar zamandır resim kursu aldığı değişkenine göre farklılık göstermemektedir. 
Tablo 20

Öğrencinin Ders Dışında Haftada Kaç Saat Resim Yaptığı Değişkenine Göre Resimde Mekân İçin ANOVA Testi Betimsel Istatistikleri

\begin{tabular}{llccc}
\hline & & $\mathbf{n}$ & $\bar{x}$ & ss \\
\hline Resimde mekân & 1-2 saat & 40 & 0,852 & 0,166 \\
kavramı ile ilgili genel & 3-5 saat & 41 & 0,833 & 0,247 \\
bilgi & 6-10 saat & 14 & 0,893 & 0,124 \\
& 11 ve fazla saat & 2 & 1,000 & 0,000 \\
& Total & 97 & 0,853 & 0,199 \\
resimde mekân & 1-2 saat & 40 & 0,598 & 0,204 \\
& 3-5 saat & 41 & 0,618 & 0,176 \\
& 6-10 saat & 14 & 0,629 & 0,194 \\
& 11 ve fazla saat & 2 & 0,500 & 0,085 \\
& Total & 97 & 0,609 & 0,188 \\
\hline
\end{tabular}

Tablo 20'de görüldüğg̈ gibi, öğrencinin ders dışında haftada kaç saat resim yaptığı değişkenine göre resimde mekân için betimsel istatistikler gösterilmiştir.

Tablo 21

Öğrencinin Ders Dışında Haftada Kaç Saat Resim Yaptığı Değişkenine Göre Resimde Mekân İçin ANOVA istatistikleri

\begin{tabular}{llrrrrr}
\hline & & \multicolumn{3}{c}{ Kareler } \\
& & Kareler Toplamı & sd & Ortalaması & F & p \\
\hline Resimde mekân & Gruplar arası &, 083 & 3 &, 028 & 0,689 &, 561 \\
kavramı ile ilgili & Gruplar içi & 3,722 & 93 &, 040 & & \\
genel bilgi & Toplam & 3,805 & 96 & & &, 794 \\
resimde mekân & Gruplar arası & 0,037 & 3 &, 012 & 0,343 & \\
& Gruplar içi & 3,370 & 93 &, 036 & & \\
& Toplam & 3,407 & 96 & & &
\end{tabular}

Tablo 21'de görüldüğü gibi, öğrencilerin resimde mekân kavramı ile ilgili genel bilgileri $(F=0,689 s d=3-93 p=0,561)$ ve resimlerinde mekân tutumları $(F=0,343 s d=3-93 p=0,794)$ onların Ders dışında haftada kaç saat resim yaptığı değişkenine göre farklııık göstermemektedir.

\section{SONUÇ, TARTIŞMA VE ÖNERILER}

Araştırmada elde edilen bulgular sonucunda, Resim Anasanat Atölye öğrencilerinin büyük çoğunluğunun mekân kavramının tanımını, mekân kavramını oluşturan elemanları biliyor oldukları ve sanat eserlerindeki mekânı diğer öğelerden ayırt edebiliyor oldukları tespit edilmiştir. Öğrencilerin sanatçıların eserlerindeki mekânları sanat akımlarına göre ayırt ederken neredeyse yarısının bu bilgiye sahip olmadığı görülmüştür. Resim Anasanat Atölye derslerinde eser incelemede resimlerdeki mekânı, sanatçıların eserlerindeki mekânları sanat akımlarına göre ayırt edebilmelerini sağlamak için bir ihtiyaç olduğu sonucunu ortaya çıkarmaktadır. Çıkan bu sonuç; sadece Resim Anasanat Atölye dersinde değil Sanat Tarihi, Yapıt Çözümleme, Batı Sanatı, Türk Sanatı gibi teorik derslerde öğrenilmesi beklenen bilgilerin özümsenmediğini ya da kalıcı olmadığını ve Resim Anasanat Atölye derslerine bu bilgilerin yansıtılamadığını göstermektedir. Öğrencilerin bu ayrımın yapılabilmesi için dersin teorik saatleri içerisinde farklı sanat akımlarındaki sanatçıların eserlerinin mekân kavramı açısından incelenmesinin bu sorunun çözümüne katkı sağlayacağı düşünülmektedir. Resimde mekân kavramında 
öğrencilerin karşı karşıya kaldığı tespit edilen bu sorunun çözümünde gelişmiş ülkelerin sanat eğitimi programlarından da faydalanılabilir. Per Dabancalı'ya (2015) göre, "görsel sanat eğitiminde karşılaşılan sorunlar karşısında eğitimcilerin geniş bir bakış açısına sahip olması, çok yönlü ve alternatif çözüm yolları üretmeye açık olmalarını sağlamak amacıyla gelişmiş ülkelerin sanat eğitimi programlarını incelemenin faydalı olacaktır" (s. 140). Ayrıca bu programları incelemek Anasanat Atölye Resim dersinde öğrencilerin "mekân kavramı ile ilgili verilen bilgiyi yeterli görmedikleri tespitine" de katkı sağlayacaktır.

Öğrencilerin Resim Anasanat Atölye derslerinde resimlerini oluştururken büyük çoğunluğunun mekânı kurgulayarak oluşturduğu ve mekânı sadece boşluk olarak kullandığı belirlenmiştir. Mekân, sadece boşluk olarak algılandığı için, kavramın yeterince özümsenmediği ve öğrencilerin resmin diğer plastik öğeleriyle bağı kuramadığı düşünülmektedir. Beyhan'a (2007) göre, kütlelerin kapladıkları yer, yani sahip oldukları uzam ile kendi mekânlarını yaratmakta, birden fazla nesne arasındaki konum, oran, açık-koyu ve renk ilişkileri, sınırsız bir boşluğun uzayda mekân olgusunu kavramamıza olanak verecektir (s. 85).

Araştırmada, bazı öğrencilerin derste mekânı nesneler ile oluşturmayı seviyorken, bazılarının modelle ilişkilendirerek kullanmayı sevdikleri, mekân oluşturmak istedikleri ve yarısından fazlasının mekânı önemsediği tespit edilmiştir. Öğrencilerin çoğunluğunun mekânı ders öncesinde ya da sonrasında bilgisayar programında tasarlamayı sevmedikleri belirlenmiştir. Öğrencilerin neredeyse genelinin iç ve dış mekânı birlikte oluşturmayı sevmedikleri bu yüzden tercih etmedikleri saptanmıştır. Öğrencilerin çoğunluğunun mimari mekânlar çalışmayı ve neredeyse yarısının ise kent görünümlerini çalışmayı sevmediği tespit edilmiştir. Bunun yanı sıra çoğunluğunun sokak görünümü çalışmayı, neredeyse yarısının ise köy görünümü çalışmayı tercih ettiği tespit edilmiştir. Öğrencilerin neredeyse yarısının mekânı oluşturmasının çok zamanını aldığı belirlenmiş, bunun da ders saati açısından bir kayıp olduğu düşünülmektedir.

Araştırmanın sonucunda; Anasanat Atölye dersi resim öğrencilerinin resimde mekân kavramı ile ilgili genel bilgileri ve resimde mekân tutumları onların cinsiyetine göre farklılık göstermiş, kız öğrencilerin resimde mekân kavramı ile ilgili genel bilgileri erkek öğrencilere göre daha yüksek olduğu belirlenmiştir. Anasanat Atölye dersi resim öğrencilerinin resimde mekân kavramı ile ilgili genel bilgileri onların okumakta olduğu üniversite değişkenine göre farklılık göstermemiş, fakat Anasanat Atölye dersi resim öğrencilerinin resimde mekân tutumları onların okumakta olduğu üniversite değişkenine göre farklıık göstermiştir. Ayrıca, Abant İzzet Baysal Üniversitesi öğrencilerinin resimde mekân tutumları Trakya Üniversitesi öğrencilerine göre daha olumlu olduğu belirlenmiştir.

Öğrencilerinin resimde mekân kavramı ile ilgili genel bilgileri ve resimlerinde mekân tutumları onların mezun olduğu lise değişkenine göre farklılık göstermemiştir. Güzel Sanatlar Lisesinden mezun olarak gelen öğrenci ile diğer liselerden gelen öğrencilerin mekân ile ilgili genel bilgileri ve tutumları arasında fark bulunamamıştır. Anasanat Atölye dersi resim öğrencilerinin resimde mekân kavramı ile ilgili genel bilgileri ve resimlerinde mekân tutumları onların yetenek sınavını kazanmadan önce resim kursu alıp almadığı değişkenine ve onların ders dışında resim yapıp yapmadığı değişkenine göre farklılık göstermemektedir. Öğrencilerin resimde mekân kavramı ile ilgili genel bilgileri ve resimlerinde mekân tutumları onların yaşlarına göre ve sınıf değişkenine göre farklılık göstermemektedir. Bu sonuçta öğrencilerin mekân kavramı ile ilgili genel bilgi ve tutumlarında bir ilerleme olmadığını göstermekte, ders içeriğinde konu ilgili bir sorun olduğunu düşündürmektedir. Öğrencilerin resimde mekân kavramı ile ilgili genel bilgileri ve resimlerinde mekân tutumları onların ne kadar zamandır resim kursu aldığı değişkenine göre ve onların ders dışında haftada kaç saat resim yaptığı değişkenine göre farklılık göstermemektedir. 
Araştırma da elde edilen bulgular ve sonuçlara bağlı olarak öneriler şu şekildedir:

1.Güzel Sanatlar Eğitimi Bölümü Resim-iş Eğitimi Anabilim Dallarında öğrencilerin Anasanat Atölye çalışmalarını yapabilecekleri farklı eğitim ortamları oluşturulmalıdır. Farklı bir ortamdaki farklı bir bakış açısı resimlerindeki mekân olgusunun gelişimine katkı sağlayabilir.

2.Güzel Sanatlar Eğitimi Bölümü Resim-iş̧ Eğitimi Anabilim Dallarında seçmeli olarak mekân dersinin açılmasının öğrencilerin farklı sanat akımlarındaki sanatçıların eserlerindeki mekânları ayırt edebilmeleri açısından yararlı olacağı düşünülmektedir.

3.Güzel Sanatlar Eğitimi Bölümü öğrencilerinin neredeyse yarısının mekânı oluşturmasının çok zamanını aldığı belirlenmiştir. Bunun da ders saati açısından bir kayıp olduğu düşünülerek mekânı oluştururken zamanı iyi değerlendirebilmeleri için öneriler geliştirilebilir.

4.Güzel Sanatlar Eğitimi Bölümü Resim öğrencilerinin resimde mekân tutumlarının arttırılmasına yönelik çalışmalar yapılabilir.

5.Resimde mekân konusundaki problemlere bağlı olarak öğretmenlerin görüşlerini belirlemeye yönelik araştırmalar yapılabilir.

6. Resimde mekân konusu ile ilgili deneysel çalışmalar yapılarak öğrencilerin bu konu ile ilgili resimleri incelenebilir.

7.Resim Anasanat Atölye derslerinde, çalışmanın uygulama kısmına geçilmeden önce, dersin teorik kısmında, öğrenci tarafından konu kurgulanırken, mekân hakkında bilgiler sanat tarihindeki önemli sanatçıların eserlerinde mekânı nasıl ele aldıkları işlenerek ve daha sonraki aşamada öğrencilerin uygulamaya geçmeleri, mekân kavramını daha iyi algılamaları yönünden faydalı olabilir.

8.Resim Anasanat Atölye öğrencilerinin, resmin plastik öğelerini kavramaları için (özellikle mekân kavramı), sanat tarihçi ve sanat eğitimcileriyle beraber, müze ve resim galerisindeki eserleri birebir çözümlemeleri faydalı olacağı düşünülmektedir.

9.Resim Anasanat Atölye öğrencilerinin atölyelere geçmeden önce, daha fazla saat sanat tarihi, yapıt çözümleme, sanat sosyolojisi, sanat felsefesi, estetik gibi dersleri almaları, eserlerini oluştururken fikir ve uygulama aşamalarında daha nitelikli çalışmalar üretmelerine faydalı olacağı düşünülmektedir.

\section{KAYNAKLAR}

AKST Bilgi Kataloğu (2016a). Abant izzet Baysal Üniversitesi, AKST Bilgi Kataloğu, http://bologna.ibu.edu.tr/Catalog.aspx?lang=trTR\&opID=341\&pmID=3872\&oID=21\&s=6 \&tak=14 (Erişim Tarihi: 2016, 23 Eylül).

AKST Bilgi Kataloğu (2016b). Abant İzzet Baysal Üniversitesi, AKST Bilgi Kataloğu, http://bologna.ibu.edu.tr/CourseDetail.aspx?lang=trTR\&opID=341\&pmID=3872\&mid=1 87615\&DersID=18304\&dersKodu=113002372011 (Erişim Tarihi: 2016, 23 Eylül).

Beyhan, C. (2007). Mekân Kurgusu ve 20 yy Resim Sanatında Yansımaları. (Sanatta Yeterlik Eser Metni). Mimar Sinan Güzel Sanatlar Üniversitesi, İstanbul.

Gür, Ş., Ö. (1996). Mekân örgütlenmesi. Trabzon: Gür Yayıncılık.

Hausman, J. J. (1985). Training of Teachers. The Internatıonal Encylopedia of Education Editors, in chief Torsten Husen T.Neville Postleth waite (s.301-304). US: Pengamen Pres.

Karasar, N. (1984). Bilimsel araştırma metodu. Ankara: Hacettepe Taş Kitapçılık. 
Karasu, F. (2006). Resimde Çıplak Gövdeyi Algılama Bağlamı Olarak Mekân. (Yayımlanmamış Yüksek Lisans Tezi). Çukurova Üniversitesi, Adana.

Kırısoğlu, O., T. ( 2005). Sanatta eğitim. Ankara: Pegem Yayıncılık.

Öztuna, H., Y. (2007). Görsel illetişimde Temel Tasarım, İstanbul: Tibyan Yayıncılık.

Per Dabancalı, M. (2015). A Comparative analysis of the colour subject between Canada Saskatchewan State and Visual Arts Education Curriculum in Turkey, journal of education and training studies, Published by Redfame Publishing, 3(6), (pp. 140-150).URL: http://jets.redfame.com doi:10.11114/jets.v3i6.991

Resim-iş Öğretmenliği Lisans Programı (2016). Trakya Üniversitesi Eğitim Fakültesi Resim-Iş Öğretmenliği Lisans Programı Ders içerikleri, http://bys.trakya.edu.tr/file/open/74322990 (Erişim Tarihi: 2016, 27 Eylül).

San, i. (1987). Çocuğun ve gencin sanat eğitimi. Milliyet Sanat Dergisi, Sayı 162.

Sözen, M. ve Tanyeli, U. (2011). Sanat kavram ve terimleri sözlüğü (11 Basım). İstanbul: Remzi Kitabevi Yayınları.

Uysal, M., A. (2009). Sanatta Mekân Algısı (Mekânla Oynamak). (Sanatta Yeterlik Eseri Çalışması Raporu). Hacettepe Üniversitesi, Ankara.

Ülker, D. (2014). Mekân Yanılsamasından Resim Yüzeyine Espas. (Yayımlanmamış Yüksek Lisans Tezi). Anadolu Üniversitesi, Eskişehir.

Yüksek Öğretim Kurulu Başkanlığı (1998). Eğitim fakültesi öğretmen yetiştirme lisans programları.http://www.yok.gov.tr/documents/10279/30217/Egitim_fakultesi_ogretme n_yetistirme_lisans_programlari_mart_98.pdf/5e166018-b806-48d5-ae13-

6afd5dac511c (Erişim Tarihi: 2016, 23 Eylül). 


\section{SUMMARY}

The study group comprises a total of 101 students from Education Faculty, Fine Arts Education Department, Painting-Handcraft Department, Painting Major Workshop Students of Trakya University in Edirne Province and Education Faculty, Fine Arts Education Department, Painting-Handcraft Department, Painting Major Workshop Students of Abant İzzet Baysal University in Bolu Province. The study aims to answer such questions relating to students in Faculties of Fine Arts, Fine Arts Education Department, Painting-Handcraft Major within the scope of the Painting class as "Do students have fundamental knowledge of location in painting? What are the issues they face with respect to location in painting? How do they create location in painting? Do they find the information imparted in Major Workshop classes on location in painting? How important do they consider location in their paintings?" as influenced by factors in Location in Painting Scale which constitute the fundamental issue of the study such as gender, class, university, high school graduated, previous painting class (if any) prior to achieving the aptitude test, how many years of painting classes taken (if any), painting outside the class (if any), how many hours of painting outside the class (if any). The study aims to find the influence of such factors and evaluates as per the aforesaid factors. The "Location in Painting Scale" and "Personal Information Form", prepared for the subject of location in painting, have been used in the study. In this study, In this study, the opinions of students on the subject of location in painting have been examined and the factors in personal information form have been evaluated in comparison with the questions in the "Location in painting scale".

The study has found that some students prefer to create the location in painting with objects, while others prefer to use it by associating with models, they want to create the location and more than half of the students considered location to be important. It has been found that the majority of students do not prefer to design the location on a computer before or after the painting class. It has been determined that the generality of students don't like to and do not prefer to create interior and exterior location together. It has been found that the majority of students do not enjoy working with architectural locations and almost half do not enjoy working with urban scenes. Additionally, it has been established that most of the students prefer to work with street scenes, and almost half prefer to work with village scenes. It has been found that more than half of the students take too long to create the location, which is considered a loss of class time.

The study has concluded that the Major Workshop class painting students' general knowledge of location in painting and their attitude towards location in painting varied according to their genders, where female students were found to have more general knowledge of location in painting compared to male students. Major Workshop class painting students' general knowledge of location in painting did not vary by the university where they study, while their attitudes varied according to their university. Furthermore, it has been found that students of Abant izzet Baysal University had a more positive attitude towards location in painting compared to the students of Trakya University.

Students' general knowledge of location in painting and their attitude towards location in painting did not vary according to the high school they graduated. The general knowledge of location in painting and attitude towards location in painting in students of Major Workshop class did not vary according to any painting classes taken prior to the aptitude examination or painting outside the class. Students' general knowledge of location in painting and attitude towards location did not vary by their age or class. Students' general knowledge of and attitude towards location in painting did not vary according to how long they have been taking painting classes and how many hours of painting they do outside the class.

The following have been suggested in line with the findings and conclusions of the study:

Various training settings can be established for Painting-Handicraft Major students to conduct Major Workshop activities. Providing optional classes for location in Painting-Handicraft Departments may be advantageous for students to distinguish the use of location in the works of artists from various art movements. Activities may be carried out to increase the awareness painting students towards location in painting. 